\title{
Informal economy entrepreneurs from Sub-Saharan Africa: observations from Kenya
}

Book or Report Section

Accepted Version

Holt, D. and Littlewood, D. (2014) Informal economy entrepreneurs from Sub-Saharan Africa: observations from Kenya. In: Georgakopoulou, A. and Spilioti, T. (eds.) The Routledge companion to business in Africa. Routledge companions in business, management and accounting. Routledge, Abingdon. ISBN 9780415635455 Available at http://centaur.reading.ac.uk/36917/

It is advisable to refer to the publisher's version if you intend to cite from the work. See Guidance on citing.

Publisher: Routledge

All outputs in CentAUR are protected by Intellectual Property Rights law, including copyright law. Copyright and IPR is retained by the creators or other 
copyright holders. Terms and conditions for use of this material are defined in the End User Agreement.

\section{www.reading.ac.uk/centaur}

\section{CentAUR}

Central Archive at the University of Reading

Reading's research outputs online 

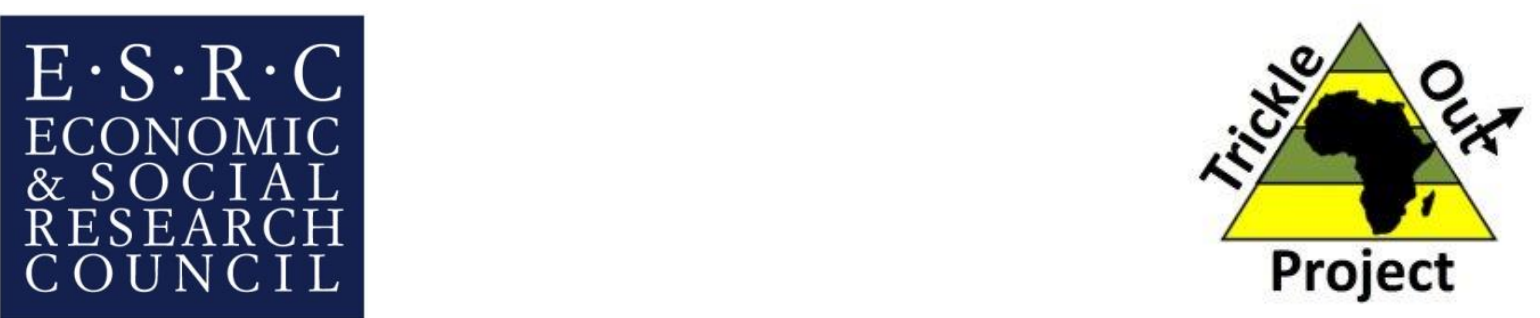

\title{
Informal economy entrepreneurs from Sub- Saharan Africa: Observations from Kenya
}

\author{
Dr Diane Holt \\ (Essex Business School, University of Essex) \\ Dr David Littlewood \\ (Henley Business School, University of Reading)
}

Correspondence Address:

Dr. Diane Holt, Senior Lecturer in Management, Essex Business School, University of Essex

Wivenhoe Park, Colchester CO4 3SQ, United Kingdom, T 01206873305 E dholt@essex.ac.uk

\section{Acknowledgements:}

The authors would also like to acknowledge the financial support of the Economic and Social Research Council (ESRC grant reference RES-06I-25-0473).

Further information on the Trickle Out Africa Project can be found at www.trickleout.net

\section{Accepted for publication. Forthcoming June 2014.}

Cite as:

Holt, D. and Littlewood, D. (forthcoming) Informal economy entrepreneurs from Sub-Saharan Africa: Observations from Kenya In S. Nwanko and K. Ibeh (Eds.) The Routledge Companion to Business in Africa., Routledge 978-0-4I563545-5 


\begin{abstract}
This chapter focuses on the role of informal economy entrepreneurs as a route to market for locally and internationally sourced goods within a Sub-Saharan African context. It draws upon interview and observational data collected during extended fieldwork in Kenya and across a number of other countries in Southern and Eastern Africa. The chapter presents four supply chain maps that typify the route to market for many products in an African context, and explores the role that enterprises and individual entrepreneurs based in both the formal and informal economy play within these supply chains.
\end{abstract}

Keywords: supply chains; informal economy; Kenya; Africa

\title{
Introduction
}

Estimates suggest that in Sub-Saharan Africa the informal economy contributes $75 \%$ of nonagricultural employment, $61 \%$ of urban employment and up to $92 \%$ of new jobs (Commission for Africa, 2005). Kiss et al. (2009) suggests that up to $70 \%$ of the world's population live in base-of-thepyramid (BoP) 'markets' (after Prahalad, 2004). In developing countries the majority of own-account, micro and small firms (MSEs) are single persons working alone (Mead and Liedholm 1998), with many of them located in the informal economy. For instance it is suggested that in Kenya, MSEs may provide all income in over half of urban households (Daniels, 1999), and that over $40 \%$ of households have at least one family member operating an MSE (Leidholm, 2002). In 2006 informal economy employment in Kenya was estimated at 6 million, in contrast to the estimated 2 million working in the formal economy (Kapila, 2006). Yet researchers know little about the entrepreneurial processes and supply chain dynamics emerging within in these kinds of unregulated and hidden economies, particularly those in Africa (Kiss et al., 20I2; Kshetri, 20I I).

The framing of many early BoP discussions (after Prahalad, 2004) focussed on low income populations as significant target markets for multinationals. More recently 'Generation 2.0' BoP discourse (after London and Hart, 2010) has focused on inclusive, co-creation strategies encouraging enterprise development and business innovation from within the poorest segments of society, often located in the informal economy. Arguably in nations with a large informal sector and weak state institutional capacity, the informal economy becomes an increasingly legitimate avenue for employment and business start-up. In such instances, businesses located in the formal economy, both national and international, may begin to consider the informal economy as a significant route to market for their products and services. For instance Kapila (2006), in a survey of purchasing behaviours in Kenya, found that $87 \%$ of respondents (including both individuals and firms in the formal economy) reported that they purchased goods and services from predominantly informal economy small producers.

In this chapter we focus on the role of the informal economy as a route to market for goods and services within a Sub-Saharan African context, by drawing on observational and interview data collected during fieldwork in Kenya, as well as our wider research elsewhere in Southern and Eastern Africa. In this chapter we model a range of examples of routes to market for local and international products emerging from the nexus of the formal and informal economies. We consider the role of informal economy entrepreneurs in the production, manufacture, wholesale and retail function of these products (after Holt et al., 20I3).

\section{Methodology of research study}

This chapter builds on research undertaken in $20 \mathrm{II}$ and 2012 across Kenya, Zambia, South Africa and Mozambique. Specifically we utilise two principal sources of data. First we draw on observational data collected across our fieldwork in these four countries, and particularly whilst travelling around Kenya visiting our case study organisations. Secondly we utilise the findings from 60 interviews undertaken with Kenyan street vendors and informal economy entrepreneurs. We have adopted a qualitative, interpretive methodology (Coviello and Jones, 2004; Gartner and Birley, 2002; Tan et al., 
2009), using a purposive and convenience sample frame. Our sampling strategy, much like that of Pisani and Richardson (20I2), required the research team to be conscious of safety considerations precluding a random sampling approach. In addition, the exploratory nature of the research informed our strategy of looking for as many different types and contexts of businesses as possible during the fieldwork, in order to better explore the diversity of informal economy enterprises that exist in Kenya and wider developing world environments.

\section{Observational Data}

This chapter also reflects our various observations on a range of informal business activities seen during our wider research programme in Sub-Saharan Africa, and in particular during more than 4 months of fieldwork research across Kenya, Zambia, South Africa and Mozambique. During this time the research team also undertook a series of in-depth case studies in these four countries mainly with social and environmental enterprises, but also with the stakeholders they interact with in their communities and along their supply chains. These twenty case studies also inform the findings of this chapter as many of these organisations interact with the informal economy as targets of their programmes, or as customers for some of the products they sell. During the interviews for the case studies we also interacted with many informal entrepreneurs, for instance individual entrepreneurs renting solar lights, craft makers, artists, builders, eco-tourism guides, home stay hosts, and metal workers. All of them were located in the informal economy, some facilitated by links with our case studies. We also met community groups, such as 32 papayas cutters harvesting in the Lake Victoria wetlands and 20+ community members involved in tree seedling, ecotourism and honey production. They were again all earning an income through the informal economic activities. We estimate that an additional 85 individuals based in Kenya who were active in the informal economy without formal employment or registered income were interviewed. We also met many more in our wider case studies in Zambia, Mozambique and South Africa, and estimate we have interacted with at least 300 entrepreneurs operating in the informal and formal economies.

\section{Interview Data}

Data was also collected through semi-structured interviews with 60 individual micro or own-account enterprises across central and western Kenya. Through semi-structured interviews with each entrepreneur we explored the sourcing of their products and the raw materials they used. The approach adopted and the nature of the questions asked, was governed by the potential lack of literacy and language competencies amongst interviewees. The interviews took place at the roadside or at the place of business. Only first names were collected to ensure respondents felt unthreatened. No discussion of remuneration took place prior to the interview. At the close of the interview participants were offered a small token of thanks, consisting of an airtime voucher for Safaricom mobile services (typically this was 100 Kenya Shillings [Ksh] equating at that time to approximately $\$ 1.19$ or $\mathbf{E 0 . 7 6}$. The interviews were conducted in both English and Kiswahili, and transcribed into English for analysis. Informed consent was attained verbally after the researchers introduced themselves and explained the purpose of the interviews and nature of the research. No signatures were requested, as this was considered to be more threatening. Data was transcribed after the interviews and enhanced with photographs taken at the site. Street interviews were undertaken during December 20II and April 20I2. Of the 60 enterprises studied, $60 \%$ had a male owner/founder, 16 had a yearly license with their local administrative council, and only 10 were registered formally with the Kenyan government as businesses (see Table I). The surveyed enterprises were all retailers of goods and/or services. They were also sometimes producers, suppliers or manufacturers. They ranged from enterprises offering services such as lawnmower repair, or producing goods such as baskets, to those selling imported items such as second hand clothing (see appendix I for full list). 
Table I: Descriptive information on sampled enterprises

\begin{tabular}{|c|c|c|c|c|c|c|c|}
\hline & & Freq & $\begin{array}{l}\text { Valid } \\
\text { Percent }\end{array}$ & & & Freq & $\begin{array}{l}\text { Valid } \\
\text { Percent }\end{array}$ \\
\hline \multirow{7}{*}{$\begin{array}{l}\text { Time } \\
\text { enterprises } \\
\text { based at site } \\
\text { or in } \\
\text { operation }\end{array}$} & $\begin{array}{l}\text { Less than I } \\
\text { year }\end{array}$ & 4 & 7 & \multirow[t]{3}{*}{$\begin{array}{l}\text { Household } \\
\text { Income }\end{array}$} & No other & 30 & 56.6 \\
\hline & I-3 yrs & 15 & 26.3 & & Some but this is main & $\mathrm{II}$ & 20.8 \\
\hline & $4-5$ yrs & 7 & 12.3 & & Other income & 12 & 22.6 \\
\hline & $6-10$ yrs & $I I$ & 19.3 & $\begin{array}{l}\text { Income for } \\
\text { respondent }\end{array}$ & Only this source of income & 53 & 93.0 \\
\hline & $1 \mathrm{I}-15 \mathrm{yrs}$ & 13 & 22.8 & \multirow{6}{*}{$\begin{array}{l}\text { Number of } \\
\text { employees }\end{array}$} & None or family & 29 & 49.2 \\
\hline & $16-20$ yrs & 4 & 7 & & Occasional ad hoc support & 8 & 13.6 \\
\hline & $2 I+y r s$ & 3 & 5.3 & & Some part-time & 2 & 3.4 \\
\hline \multirow{3}{*}{$\begin{array}{l}\text { Licensed } \\
\text { with local } \\
\text { council }\end{array}$} & Has license & 16 & 26.7 & & Full time employees & 12 & 20.3 \\
\hline & No license & 43 & 71.7 & & Shared business & 8 & 13.6 \\
\hline & License in past & $\mathrm{I}$ & 1.7 & & Number FT equivalent & \multicolumn{2}{|c|}{$\begin{array}{l}\mathrm{I}, \mathrm{I}, \mathrm{I}, 2,3,3,3,3, \\
4,5,5,10\end{array}$} \\
\hline \multirow{3}{*}{$\begin{array}{l}\text { Registered } \\
\text { formally as a } \\
\text { business }\end{array}$} & Registered & 10 & 16.7 & \multirow{3}{*}{$\begin{array}{l}\text { Gender of } \\
\text { owner }\end{array}$} & Male & 36 & 60.0 \\
\hline & Nonregistered & 48 & 80 & & Female & 22 & 36.7 \\
\hline & $\begin{array}{l}\text { No but plans } \\
\text { to in future }\end{array}$ & 2 & 3.3 & & Multiple members & 2 & 3.3 \\
\hline
\end{tabular}

Kenya has an estimated population of 42 million, a labour force of around 17.9 million, and roughly $40 \%$ of the adult population is unemployed (World Bank, 20II). Kenya's Gross National Income (GNI) per capita is estimated at $\$ 790$ (equivalent to $1318 \mathrm{Ksh}$ per week per person), with $46 \%$ of the population living below the national poverty line (World Bank, 20I I). Whilst we do not claim Kenya is fully representative of all developing country institutional contexts we do believe it offers a useful glimpse into informal economy entrepreneurial dynamics in a Sub-Saharan African setting. We suggest that its study provides insights relevant for other societies with comparable levels of informality in their economies, and similar regulatory and institutional environments.

\section{The Informal Economy}

In nations where significant growth is not occurring within the formal economy, or where large/medium sized enterprises are not significantly absorbing the available labour pool, setting up a small or own-account informal enterprise is an imperfect but necessary choice for many individuals (Kapila, 2006; Schaumburg-Muller et al. 2010). In entrepreneurship research the difference between choosing to become self employed and unemployment catalysing entrepreneurship is increasingly stressed (Román et al., 20I2), indeed Gurtoo and Williams (2009) describe both necessity and/or opportunity drivers in a sample of informal Indian MSEs. Therefore informal economy enterprises can be key components of household survival strategies in the developing world, as well as in the day-to-day economic landscape of these nations, while also acting as seed beds for emerging base of the pyramid (BoP) business innovations. Some entrepreneurs make a conscious choice to exploit perceived business opportunities (or structural holes), whereas others just search for a way to earn a living when unable to find employment.

Informal economy enterprises typically trade or produce licit products but utilise either illicit distribution mechanisms or production processes (Pisani and Richardson, 2012). They rarely comply with all regulations that apply to their trade, for example concerning registration, tax payment, conditions of employment and operating licenses (Becker, 2004:14). Typically in an African context this means that they operate unregistered enterprises in unsanctioned locations, and/or fail to declare their total income for the state to capture rents through taxation, or fail to comply with the regulations that govern the operation of an enterprises in that country. There is a widespread understanding of informality based on these dimensions in Kenya, where this sector is known as the 
Jua Kali, which in Kiswahili means 'hot sun' (see King 1996) referring to those that work outside. This term has now entered common usage in Kiswahili speaking countries to refer to any kind of informal business not paying tax and not registered by the state. These Jua Kali businesses are evident across the length and breadth of Africa from rural villages, to district towns and major cities. Wherever you find people in Africa you will find some form of micro enterprise producing, distributing or retailing goods and services.

In the developing world it is possible to define this informal economy across multiple dimensions (Becker, 2004). The informal economy is traditionally regarded as the survivalist "unregulated nonformal portion of the market economy that produces goods and services for sale or for other forms of remuneration", and is often conceived negatively in terms of undeclared labour, tax evasion, unregulated enterprises, and illegal but not criminal activities (Becker, 2004:I I). Often "unprotected" (after Mazumdar, 1976), informal employers and employees may ignore legislation on minimum wages, labour rights and social security. However Kapila (2006) also notes that many of Kenya's formally registered enterprises do not adhere to labour laws or regulations concerning working conditions. Nichter and Goldmark (2009:1456) describe informality as "unregistered but derive income from the production of legal goods and services". In this chapter we adopt the definition of informal entrepreneurs proposed by Pisani and Richardson (2012:109) as "those who are self-employed working under informal means". We define informality in the context of this research on the basis of whether the business is registered with the government, pays tax, or the employment conditions it offers any staff.

Whilst this chapter does not specifically consider social purpose ventures (e.g. Neck et al., 2009) it potentially offers insights into this emerging field of research. Projects such as the BRAC ultra poor enterprise development programme in Bangladesh (Mair and Marti, 2009) are similar to many of the BoP projects, social ventures and other income generation models observed during our wider research. They involve an organisation in the formal economy interacting with actors typically located in the informal. These actors are not themselves social entrepreneurs, essentially they are Jua Kali entrepreneurs being presented with a new form of business activity to generate an income. In many ways this is no different from a second hand clothes seller, or someone producing any kind of goods along the roadside or in villages. One of our case studies, Tough Stuff Solar, operates a dual market channel strategy with products sold through formalised markets such as supermarkets and then a 'social enterprise' channel where products are sold at wholesale prices to organisations such as Christian Aid, Ecofinder Kenya (another of our case studies) and the Church World Service who then operate solar entrepreneurship schemes facilitating the sale or rental of these products as a steady source of income for BoP entrepreneurs. The facilitating agent bridges institutional voids (Mair et al. 2012), legitimises the business model in this cultural context (Meek et al., 2010) and facilitates entrepreneurial learning (Cressy, 2006) in these communities. None of these individual entrepreneurs are located in the 'formal' economy nor are they ever likely to operate as registered businesses. Here the solar products are just another type of informal economy business, given legitimacy by their adoption in these communities. A similar theme emerges in the microfranchising models emerging in the developing world, for instance the Fanmilk company in Ghana:

'The Fanmilk Company (the microfranchisor) supplies the mobile vendors (the microfranchisees) primarily through company depots. Each morning vendors retrieve their ice cream and yogurt inventory from a depot or agent's store and they return unsold products from the prior day. The depots provide vendors with bicycles and training. Vendors make a fixed profit and also receive a monthly commission from Fanmilk. While some microfranchisees sell from boxes balanced on their heads or from carts, the majority have bicycles' Christensen et al., (2010:597)

Therefore we believe that exploring a sample of MSE operating in the informal/formal economy nexus may offer wide ranging insights into supply chain dynamics and wider entrepreneurial processes in the developing world. 


\section{A journey through Kenya's informal/formal economy supply chains}

Rural product supply chains

The informal economy dominates the urban and rural landscapes of Kenya, and elsewhere in SubSaharan Africa. In rural areas the street vendors focus mostly on selling agricultural goods to passing motorists and truck drivers. Many of the items sold reflect the dominant agricultural produce of that region, so potatoes would dominate in one section of the roadscape, followed by onions, or rhubarb, or rice, or tea. Many of these products (e.g. rice, tea, potatoes) occur in specific growing zones which are a function of soil, weather and altitude. Available much cheaper in these locations they are often transported by buses, trucks and private buyers along the highways, generating a mark-up profit at each stage of their journey. Some examples include:

- Sugar cane grown in local fields along the Kisumu road and sold to truck drivers who pull over at the end of climbing lanes, they then resell this sugar cane along their routes.

- Women selling buckets of potatoes for $150 \mathrm{Ksh} / \mathrm{bag}$ at roadside junctions, sold to truck drivers, and eventually selling for $400 /$ bucket in Nairobi.

- Rows of vegetables stands displaying bags of onions (500 Ksh per pack) and oranges (200 Ksh).

- Bags of salt extracted from Lake Elementaita sold along the roadside.

- Near Nakuru hawkers selling milk and yoghurt bought from the Delamere factory shop to people on buses passing through the weighbridge area. They sell yogurt for 80Ksh (mark-up of about 10 Ksh) and milk for $30 \mathrm{Ksh}$ (5 Ksh profit).

All of these small transactions are very price sensitive, and all are located in the informal economy. In all the interviews with these kinds of sellers it was clear there was a standard price in that region for these goods. So anything that squeezed margins, like VAT or a fine or indeed tax on income, would leave them unable to compete with those that had avoided these add-on costs.

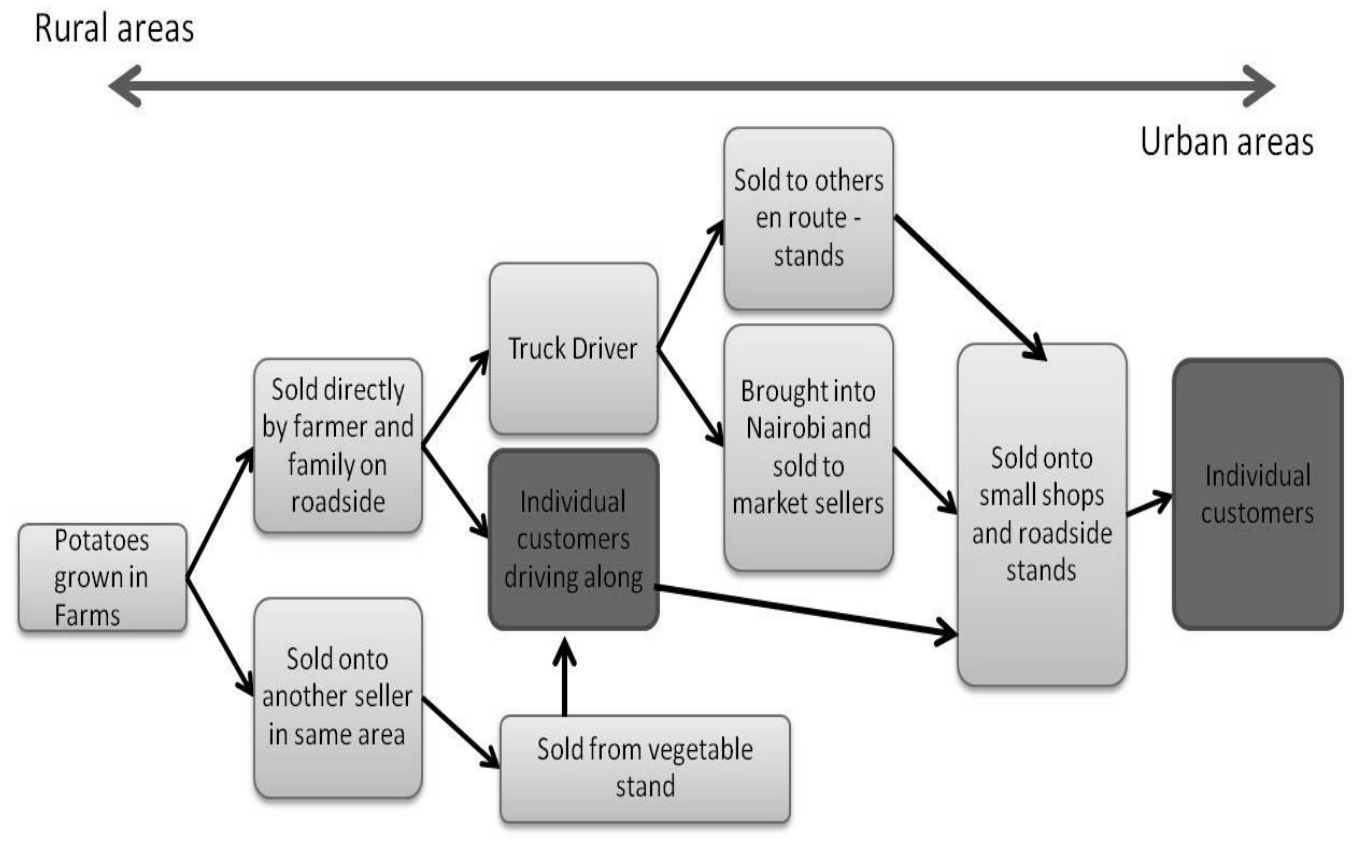

Figure I a: The rural products supply chain (e.g. potatoes)

In these rural areas the informal economy dominates the MSE sectors. There are large formal employers who employ many locally (such as the flower farms in Naivasha and tea growers in Eldoret). However many residents also supplement their incomes by selling the produce from their farms, or selling on these regional products through informal roadside trading. Grasses from Lake Victoria, charcoal, potatoes, rice and tea make their way on the roofs of buses, small 'matatu' 
minivans, with truck drivers and middlemen to the major urban areas through supply chains such as Figure Ia. The supply chain in Figure Ia is typically informal and based around agricultural products. Figures $\mathrm{Ib}$ and Ic show some examples of the kinds of goods that would be sold using this type of supply chain. Each stage in this supply chain offers opportunities for informal economy entrepreneurs to extract value and an income.

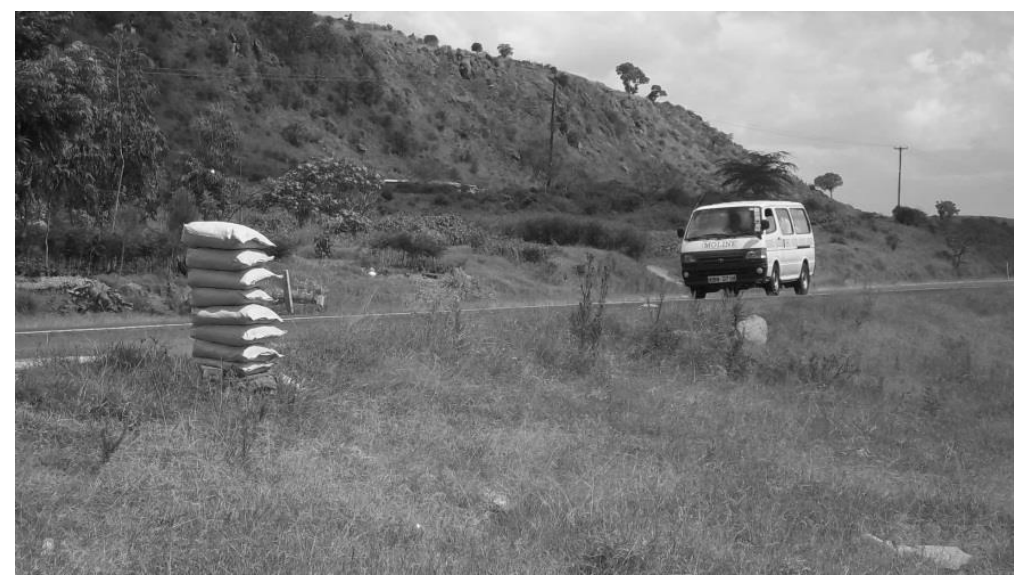

Figure Ib: Bags of salt for sale along the roadside in Nakuru

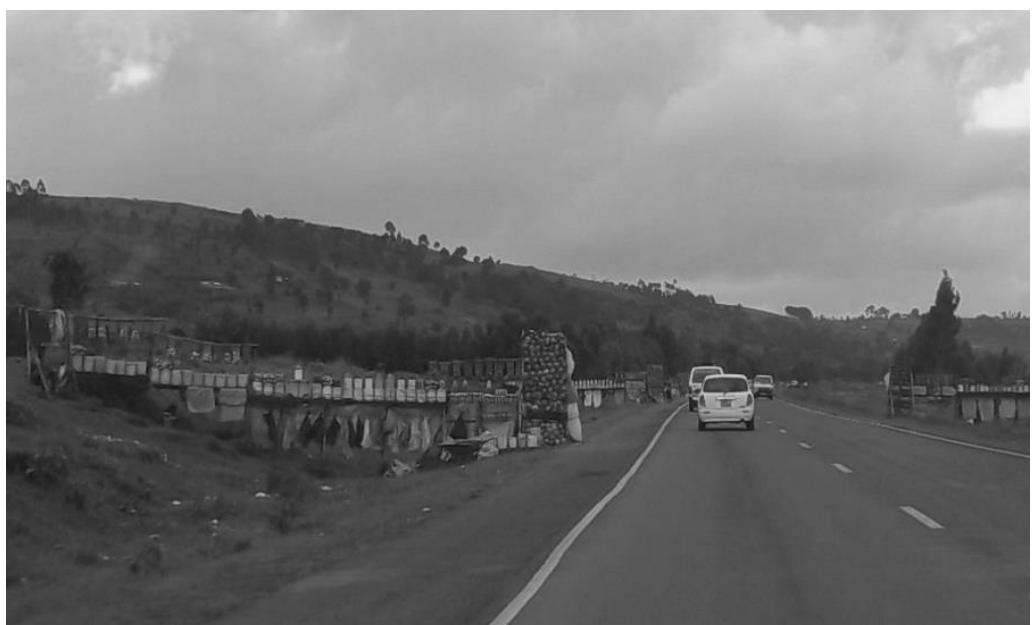

Figure Ic: Roadside vegetable seller along the road to Kisumu

In the rural supply chain model, informal economy entrepreneurs setting up businesses at the rural ends of these chains are highly imitative, with low barriers to entry in terms of capital and skills requirements. Mostly these entrepreneurs purchase from farmers or other third party sellers and then sell products on. Occasionally, as in the case of the flower farms or Delamere farms, the supplier of these goods is registered in the formal economy with the informal economy entrepreneur buying from them in a form of wholesaling. Truck drivers and other motorists form an important link in the supply chain moving these products from growing areas, into local towns and then on to the major cities. Those entrepreneurs forming part of the logistical functions in this model might work for formally registered firms, perhaps moving goods for supermarkets. They would purchase these goods unofficially and then sell them along their routes. Again there are low barriers to entry with the exception of the requirement for a vehicle. As the products move into the urban areas there is a possibility that they will be bought by registered firms, such as a small shop or supermarket. However for these more formal enterprises these products are just one of many bought and sold, not the principal basis of their business model.

Elements of isomorphism are also demonstrated in these types of businesses. Often they are found clustered in zones, such as Figure Ic which was one of over 20 identical stalls spread over 
approximately 2 miles of this major highway. Similar patterns are found at road junctions, truck stops, growing zones, and anywhere that passing traffic may be concentrated and able to pull over. Typically here the informal economy entrepreneur is a retailer or producer/retailer.

\section{Used goods supply chains}

In Figure 2a we see an example of a used goods supply chain. Here goods are sourced from formal economy producers and importers, and then sold in a supply chain which links not only the domestic formal economy with the informal, but also adds the international formal economy through the transport of consignments of goods from second-hand markets in Europe. Examples of this would be the market in mitumba (second hand clothing) as illustrated in Figure 2b, or used kitchen items (Figure 2c).

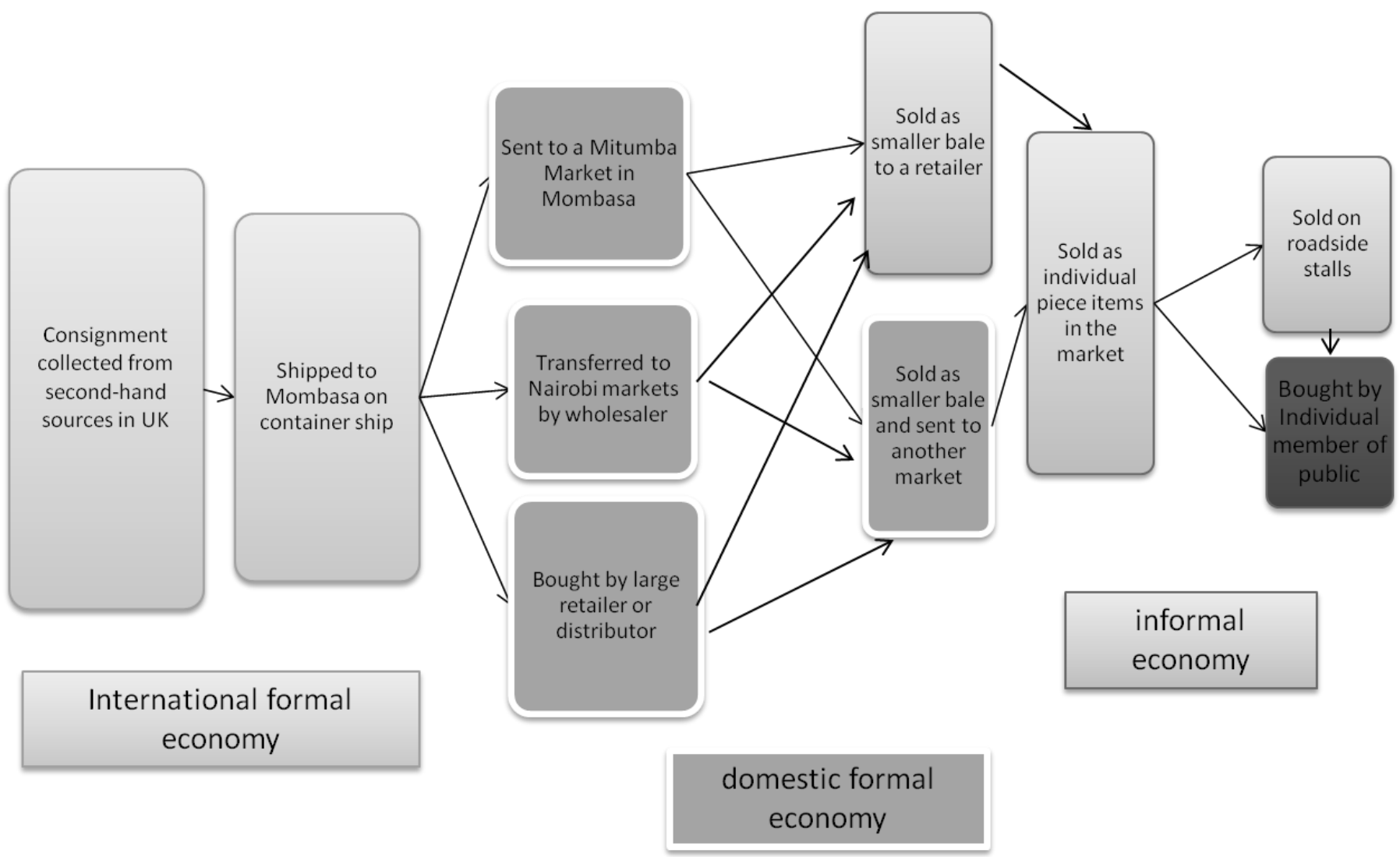

Figure 2a: A formallinformal used goods supply chain (e.g. clothing)

Typically these goods are not available from local producers, so are imported and distributed through wholesale outlets. Some items, such as used clothing, are significantly cheaper when imported. Other items such as second hand machinery, and other manufactured items such as saucepans are not available from local manufacturers or not available at the same level of quality. These imported goods in Figures $2 \mathrm{~b}$ and $2 \mathrm{c}$ make their way from Mombasa port on the East coast to Nairobi, then on to markets in provincial cities like Kisumu, and finally to a stall under a roadside tree. At each stage of this process value is extracted by an informal economy entrepreneur, or a formally registered business, who is acting as either a supplier to other entrepreneurs or as a retailer to the general public.

Here the barriers to entry for individual informal economy entrepreneurs revolve around access to capital. Tacit knowledge on these types of business models and how to source the goods is freely available in these communities. However, buying an imported bale from Mombasa has a significantly 
higher capital outlay than buying a smaller bundle in a regional market. Again at each stage individual entrepreneurs capture value by buying and selling along the supply chain. In this supply chain the the initial products are mostly sourced from overseas producers, sometimes from other developing countries like India or sometimes from second hand international markets in developed countries such as the UK. Here we see an intermingling of formal and informal economy enterprises, with these goods moving in and out of registered enterprises as they make their way from the point of import to the final end consumer.

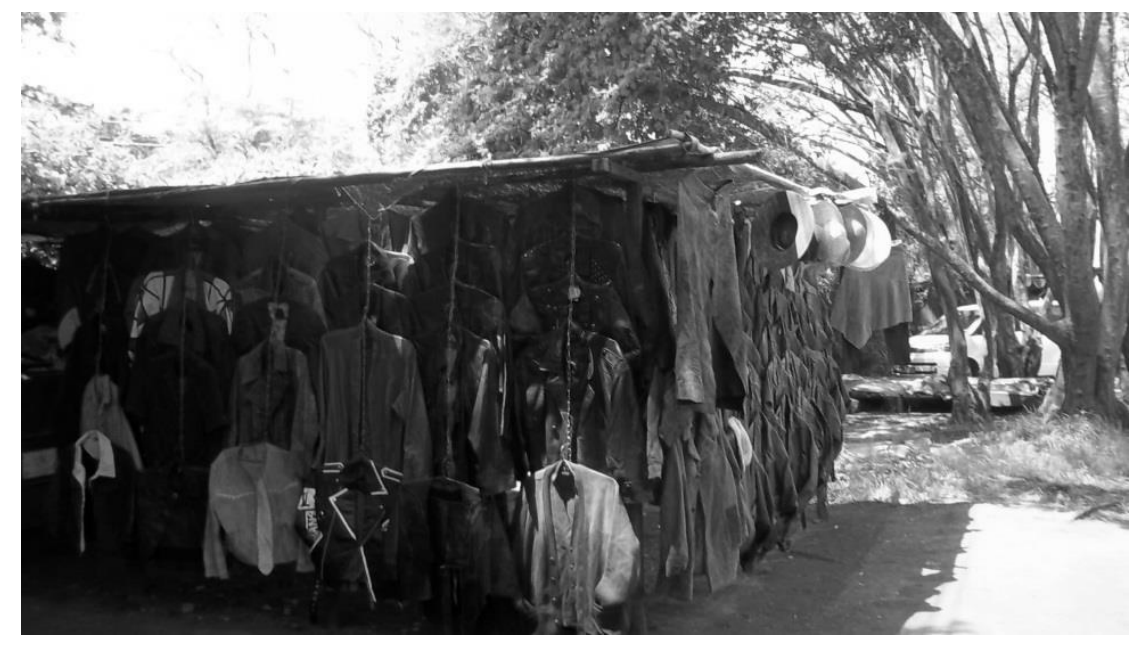

Figure $2 b$ : Imported second hand clothing

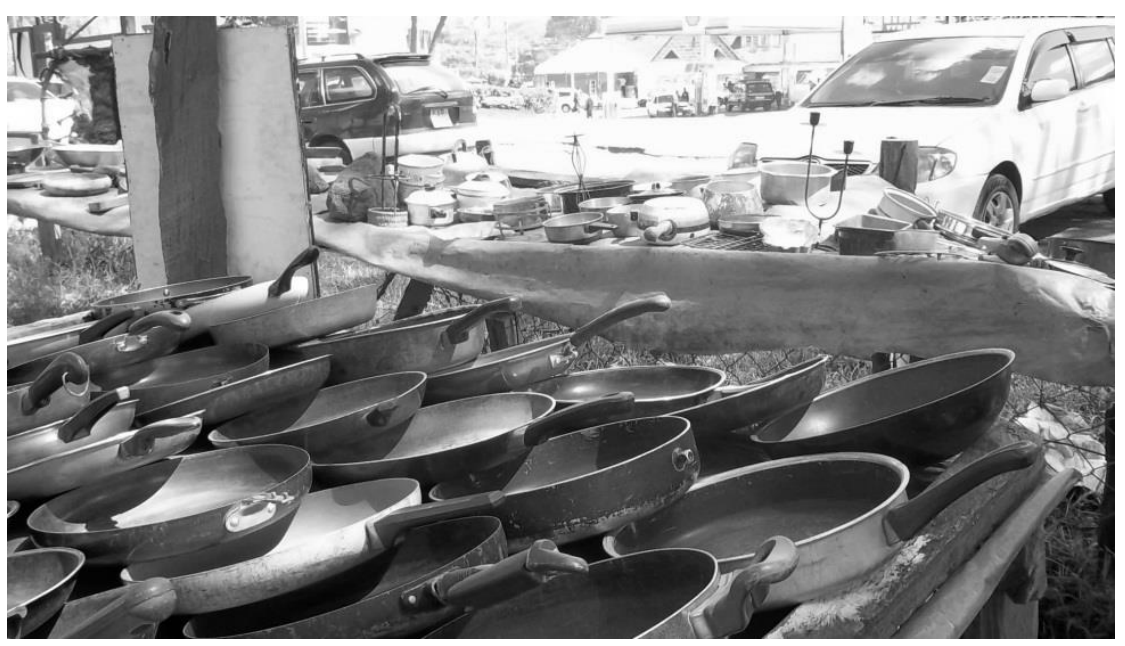

Figure 2c: Imported used kitchen items sold along the roadside in Nairobi

Formal to informal supply chains

A third form of supply chain observed at the nexus of the formal and informal economies (after Holt et al., 2013) is associated with new fast moving consumer goods, typically sourced from multinationals, as illustrated in Figure 3a. Examples include items such as mobile phone chargers and other electrical goods which are not only sold in the large retailers but again bought by small informal roadside traders selling on the pavement/stalls, or through the street hawkers selling in the stalled traffic on Nairobi's main roads. Capital is again the major barrier to entry for informal entrepreneurs focusing on these kinds of enterprises. They need to generate enough capital to buy stock, and then make sure that stock sells quickly. Anticipating demand is a key consideration, as is selecting the correct location to sell the items. Again this is a highly price sensitive market, with smaller electronic goods being sold at the road side, like car chargers for a small mark up. In the communities furthest away from the ports and larger cities the entrepreneur selling these items on the street or in a small kiosk are capitalising on the fact that not all customers can travel to cities to purchase cheaply from formal outlets. However the entrepreneur will also need to factor in their 
own costs for transport, and this is where social networks may facilitate business activities, with the entrepreneurs using relatives or friends as couriers for the products. Initiative is required to identify which products will be in demand by passing customers, although tacit knowledge on these types of business models is typically high, and easily copied if capital is available.

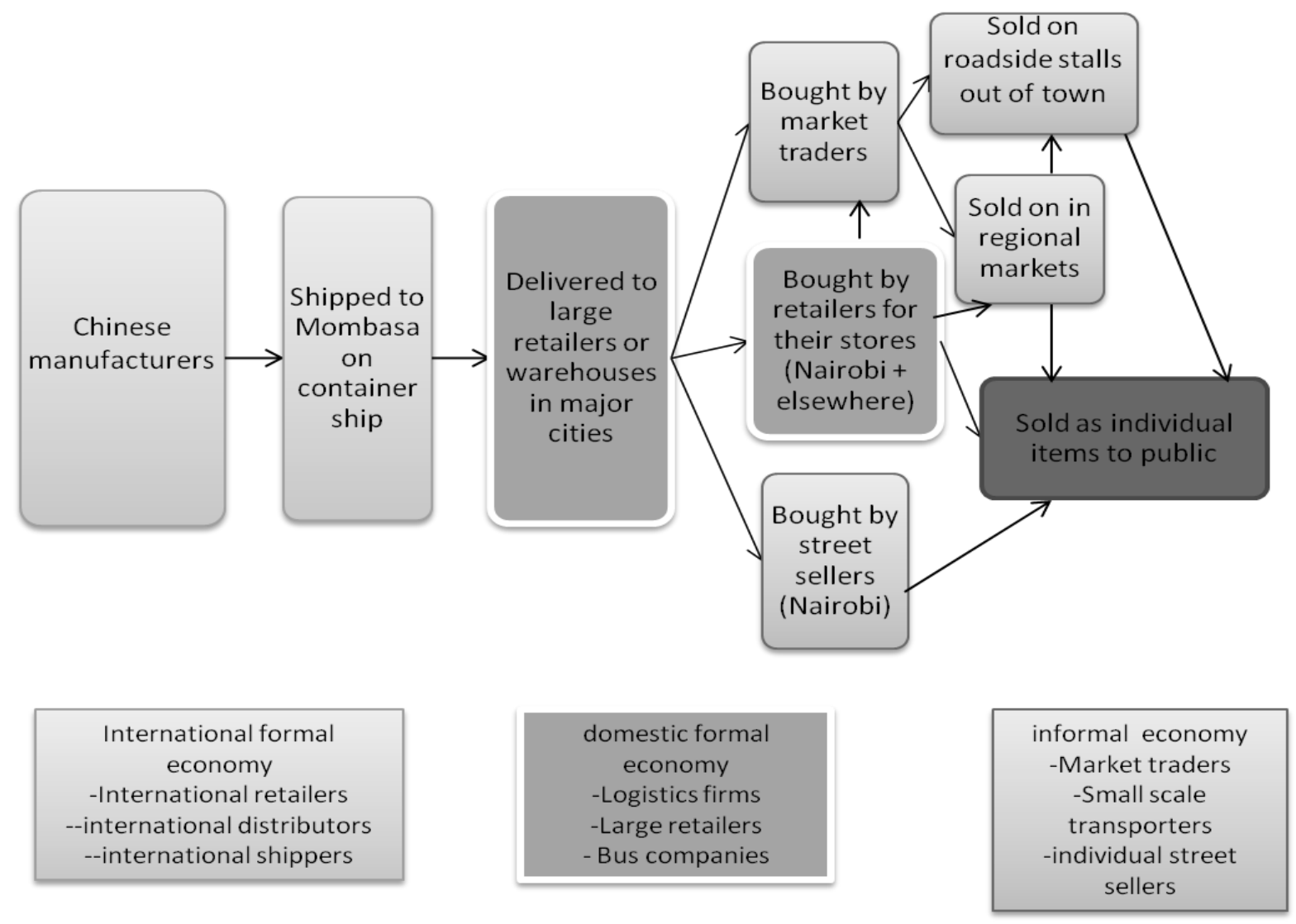

Figure 3: A typical formal to informal supply chain for new consumer goods (e.g. car chargers)

Hybrid urban/rural and formallinformal supply chains

A hybrid regional urban/rural and formal/informal economy supply chain model also emerges occurring for consumer goods produced in a specific region or nearby country. Examples here would include newspapers, craft items or furniture. An informal economy entrepreneur might buy newspapers from a formal retailer or distributor, and then sell them on highways. One of our interviewees would travel to the Turkana region in northern Kenya every 2 months and buy baskets, which he would then sell along the roadside in central Kenya near the flower farms in Naivaisha. Sometime these baskets would then be bought by formally registered tourist lodges to sell on with a profit mark up. In both instances the informal economy entrepreneurs bridge the transportation gap between the producers and the end consumer. In the case of the basket seller, by travelling the long distance to remote areas of Turkana he gains a significant extra profit when he sells the baskets on in an area where they are traditionally unavailable. Through his initiative he recognises the opportunity to increase the diversity of his product range and to attract more customers.

Hybrid supply chains can start in formal or informal economies. The direction of the supply chain may go from the formally registered producer often in an urban centre (machinery, newspapers) and then out to other smaller formally registered enterprises before moving onto informal economy sellers once the items are in small enough 'packages' to be affordable for both informal economy sellers and the end customer. Alternatively the hybrid urban-rural supply chain starts in the informal economy with informal producers often in a rural or provincial location. Examples here include 
furniture and craft items where a Jua Kali producer or farmer makes/grows the items and these are then bought by other informal sellers until they are purchased by larger registered firms such as tourist lodges, large retail outlets and international distributors. Table 2 summarises the four main supply chains that emerge from our interviews and observations.

Table 2: Summarising the informallformal supply chains

\begin{tabular}{|c|c|c|c|c|}
\hline Mode & Supply Chain Type & Source & Details & Examples in Kenya \\
\hline 1 & $\begin{array}{l}\text { Rural supply chain } \\
\text { (Figure la) }\end{array}$ & Local/ regional & $\begin{array}{l}\text { Agricultural products, } \\
\text { national or regional }\end{array}$ & e.g. Tea, Coffee, Potatoes \\
\hline 2 & $\begin{array}{l}\text { Used goods supply } \\
\text { chain (Figure 2a) }\end{array}$ & $\begin{array}{l}\text { International/ } \\
\text { Multinational }\end{array}$ & $\begin{array}{l}\text { International, imported, } \\
\text { second-hand consumer } \\
\text { goods, recycled, typically } \\
\text { by sea }\end{array}$ & $\begin{array}{l}\text { e.g. Clothing, machinery, small } \\
\text { consumer items }\end{array}$ \\
\hline \multirow[t]{2}{*}{3} & \multirow[t]{2}{*}{$\begin{array}{l}\text { Formal to informal } \\
\text { supply chain } \\
\text { (Figure 3) }\end{array}$} & $\begin{array}{l}\text { International/ } \\
\text { Multinational }\end{array}$ & $\begin{array}{l}\text { International, imported, } \\
\text { manufactured, typically } \\
\text { by sea }\end{array}$ & $\begin{array}{l}\text { e.g. new consumer goods or raw } \\
\text { materials e.g. Electronics, fast } \\
\text { moving consumer items }\end{array}$ \\
\hline & & $\begin{array}{l}\text { Cross border/ } \\
\text { International/ } \\
\text { Multinational }\end{array}$ & $\begin{array}{l}\text { International, imported, } \\
\text { raw materials, } \\
\text { sea/air/train }\end{array}$ & $\begin{array}{l}\text { e.g. Imported food products and } \\
\text { raw materials e.g. Minerals, metals, } \\
\text { exotic fruits and vegetables, other } \\
\text { foodstuff not found locally }\end{array}$ \\
\hline 4 & $\begin{array}{l}\text { Hybrid urban-rural } \\
\text { formal/informal } \\
\text { supply chain. }\end{array}$ & $\begin{array}{l}\text { Regional/ } \\
\text { National/ Cross } \\
\text { Border }\end{array}$ & $\begin{array}{l}\text { Cross border, national } \\
\text { or regional products. } \\
\text { Produced, manufactured } \\
\text { or assembled. May use } \\
\text { imported raw materials }\end{array}$ & $\begin{array}{l}\text { e.g. Local or regional commodity } \\
\text { consumer goods (produced/ } \\
\text { manufactured or remanufactured/ } \\
\text { repaired products) e.g. Furniture, } \\
\text { craft items, newspapers (national } \\
\text { and regional) }\end{array}$ \\
\hline
\end{tabular}

\section{Discussing the role of informal economy in the supply chain}

Informal economies in developing countries are inextricably linked to both domestic and international formal economies, with growth in the informal economy often crucial for growth in the formal (Schaumburg-Muller et al. 2010). It is clear from our supply chain models and the various illustrative examples presented that far from the informal economy in Africa existing as a separate discrete entity, that it is in fact an integral part of the formal economy, as a source of materials, labour and customers. Figure 5 illustrates a good example of this, showing a roadside entrepreneur selling sweets and cigarettes most likely bought from a registered firm operating a retail warehouse. These sweets and cigarettes are then sold individually on the street in a 'formal to informal supply chain'. Typically a packet of Dunhill cigarettes retails in a roadside container store for $150 \mathrm{Ksh}$ but they will also sell individual for $10 \mathrm{Ksh}$ each (equating to a $50 \mathrm{Ksh}$ profit). Here the street vendors act as intermediaries, reaching a customer base that the formalised large retailers cannot supply. The person, who buys a single cigarette or one sweet does so because they cannot afford the items in bulk. In some ways this is reminiscent of the BoP generation I.0 strategies (London and Hart, 20I0; Prahalad, 2004; Simanis and Hart, 2008) seeking to link multinationals into low income segments as a potential marketplace. These supply chains are typically mode 3 or 4 , depending on whether products originate from within-country, just across the border, or internationally where they would be imported long distances. 


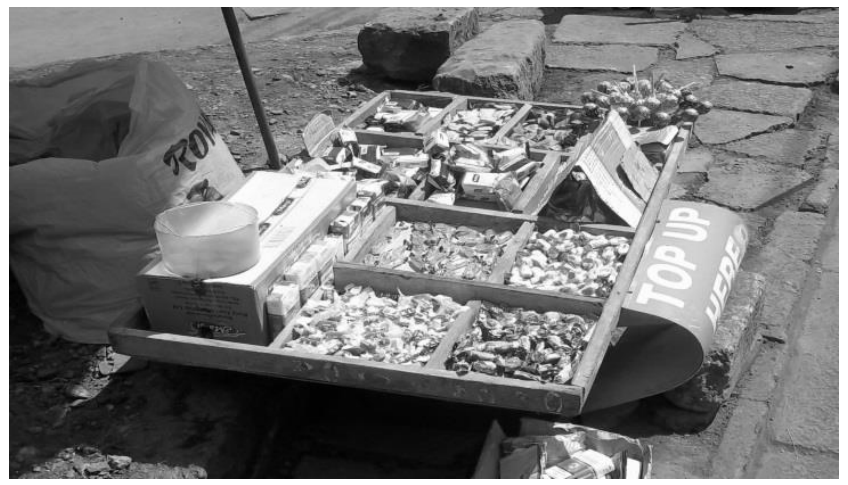

Figure 5: A street stall selling single sweets, measured rice and cigarettes

A number of our interviewees sold such goods in container stores as an informal version of the corner shop. In the container store in Figure 6 some of the products sold are likely bought from warehouses (mode 3). They would also sell perishables like eggs and bread alongside these formal products, the latter delivered to the stand by informal producers but also the delivery person (often on a bicycle) from large scale egg producers (which may be registered) (mode I and mode 4). The delivery person may be a casual employee, often without employment rights. So the informal economy also becomes a source of ad hoc labour for a registered firm. Entrepreneurs running these container stores will need to fund the initial purchase of the container, and sometime they turn to microfinance for this access to this capital.

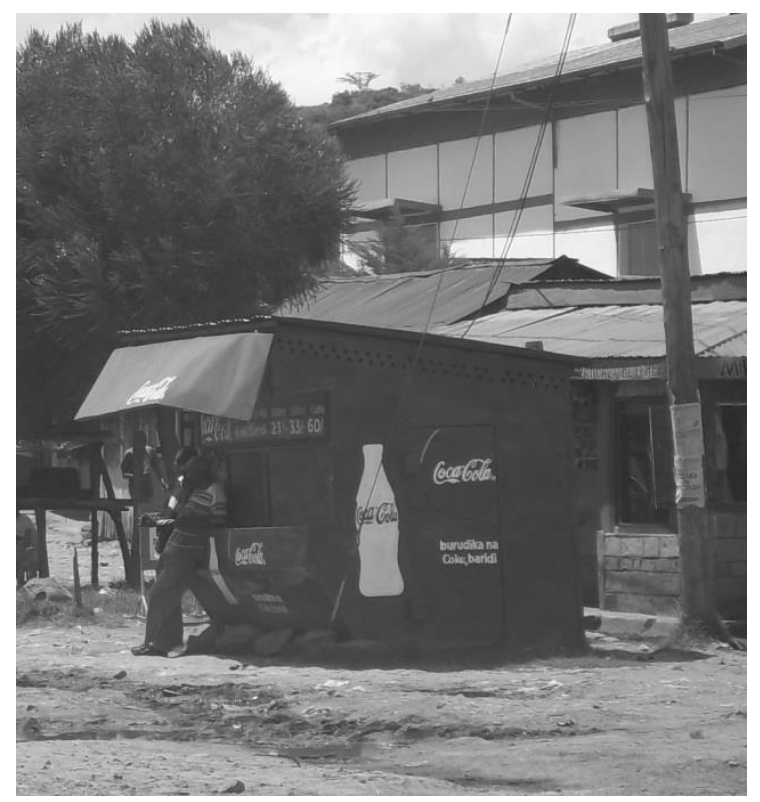

Figure 6: Typical container kiosk selling soft drinks, water, cigarettes, bread, milk, phone credit

In the cases of the market gardens found across major towns and cities, the producers will buy seeds from a large retailer (mode 3), polythene to make the wrapping around the roots from a store, and the clay pots from a factory. One of the major customers for the factories producing these clay pots is these market garden sellers who line the streets of every major town in Kenya. Sometimes these pots are bought by large formally registered firms who then retail them to customers in shopping malls (mode 4).

The small transporters (often informal economy matatus or someone with a truck for a small cash payment) are important links in the distribution chain. M-Pesaii, the electronic mobile phone money transfer system, is also now playing a major role in facilitating these kinds of formal-informal economy interactions. Now a customer can call for a part for a machine they are repairing, pay by an M-Pesa transfer, and then the item is placed on a local bus to be delivered. In the case of a basket maker in Nairobi the grasses used to make their products were collected from the shores of Lake 
Victoria near Kisumu and then put on a local bus or matatu to be delivered to Nairobi. The reverse is also true with formal firms sourcing from the informal economy, or a quasi-informal economy business that has a receipting system, for example the safari camp that had their lawnmower repaired by one of our respondents, or a business who buys furniture from the 'fundis' (technicians) along the roadside.

In Kisumu we visited a small weaving firm, formally registered, that works in a similar manner, placing the items to be sold on consignment in Nairobi on the bus for transport. All of these small scale interactions demonstrate that the informal and formal economies are linked by a complex, often highly individualized network and flow of goods, services, money and labour interweaving in and out of both formal and informal organisations.

\section{Implications for future research and theory}

A number of research questions emerge when considering these linkages between the formal and informal economies, especially through supply chains. Firstly we suggest that the flow of goods and capital from the informal economy into the formal economy is relational and moderated by trust and risk, whereas the flow of goods and capital from the formal into the informal is likely to be a more of a transactional process. The role of trust in developing and transitional economies is explored in more detail by Tan et al. (2009) in China, and Nguyen and Rose (2009) in Vietnam. Essentially we propose that a firm fully embedded in the formal economy (often larger, maybe even international) will need to trust their informal economy suppliers to deliver goods on time and to the appropriate quality, making the building of a two-way relationship more likely. Whereas sourcing from the formal is much more of a transactional function. We suggest that future work should explore these supply chain relationships between the formal and informal actors.

Our findings support observations about the role of mobile phones in the MSE Oke clothing supply chains in southwest Nigeria, where they facilitate the flow of information and ameliorate supply chain problems associated with risk, speed and cost, along with economising effects and travel substitution (Jagun et al., 2008). Indeed, we suggest M-Pesa is a broad ranging macro innovation with the potential to reinforce, and perhaps expand trade within the informal economy. For now M-Pesa removes the need for trust in an individual hand delivered payments to suppliers which are so open to abuse, and also decreases time lags between ordering and delivery. We suggest that more research is needed on the role of M-Pesa in supply chains.

Nichter and Goldmark (2009) suggest that one of the conditions for the transition to formality is the visibility of an organisation to officialdom. Kapila (2006) suggests a key criterion distinguishing most informal Kenyan MSEs is their local markets and distribution channels. Thus we suggest a firm supplying a large formally embedded organisation, such as the government or a supermarket, might move towards formality more readily than one linked by multiple intermediaries. Indeed it does seem from our findings that one factor that promotes formality amongst our Kenyan sample is a supplier relationship with the formal economy. It seems the closer the MSE is linked through their supply chain as a supplier to large formal bodies or companies, the more likely they are to register, although this is not always the case. Therefore exploring the influence of close ties with formal firms as a supplier is an important area for future exploration.

The informal seller is a key component in various stages of the supply chain of a number of products in Kenya. Even the purely informal supply chain can often comprise a mix of sources, some of which rely on distribution networks that are linked to the formal economy like truck drivers. Some large formal organisations, like the flower farms or agricultural estates, sell their goods through regional 'factory' shops to those who then hawk them along the street. Reject flowers, cut at an incorrect length for the UK supermarket, are sold on and then sold on street corners. One of our case studies, a full profit social and environmental enterprise, is a distributor of modular solar products. Their products are distributed to NGOs and social projects run by organisations such as Christian Aid and also one of our other case studies. Individual entrepreneurs, all informal, are then given solar lights and charging kits on a rent to buy scheme and charge these during the day. Then 
overnight they rent these to their customers for around $20 \mathrm{Ksh}$ per night, and these are then used to run night-time fishing businesses, small sales kiosks, or in homes to help children study. The individual entrepreneur and the customers are all based in the informal economy but the technology itself is supplied by a formal firm.

Charcoal, potatoes, onions, sweet corn and many other items are produced in the rural areas and distributed by trucker drivers who are on their delivery routes for the supermarkets and other formal larger firms. A vegetable and charcoal seller along the Naivasha road and a Nairobi retailer of food stuffs describe their product mix and sourcing:

"we buy the charcoal from lorries, who pass through selling it to us and farms nearby. We buy the vegetables from nearby farms... We sell vegetables we do not need from our farms... We buy vegetables from the market and sell to others.."

"We get from Eldoret from farmers or someone in stalls there. Use those trucks trailers that are coming from Uganda if they are empty. Beans from Kisii." ( sells cereals, maize and beans in Kengemi in Nairobi)

For large multinationals the informal seller can be a key component of reaching their customer base. These routes to market are too small for the organisation to pursue on an individual basis but may form a significant channel for the distribution of everything from Coke Cola to cigarettes and car chargers. The informal entrepreneur exploits the opportunity offered by the 'structural hole' (Burt, 1992) formed outside the dense relationship of networks in the formal economy. Considering the informal economy as a legitimate route to market should be explored further, especially how large multinationals and registered regional corporations are engaging with this hidden supply chain and understanding more about the volume of sales through these channels.

The 'informal' distribution networks may also be linked to neighbouring countries and even international supply chains; for instance our seller of perfume from Dubai, and traditional cloth (vitenge) from Tanzania. The sellers of second hand goods are also selling on items that have perhaps been made in China or India, and then used in the EU, before being shipped to Africa (such as second hand clothing and used kitchen items). Within our sample of 60 businesses 17 were selling recycled or second-hand items. The influence of these distribution networks which mix formal and informal economic activity both domestic and international are also a fruitful area for future research.

An interesting phenomenon that was also observed in our interviews was the process of 'trading up' by capturing more of the value in the supply chain either through capturing more links in the supply chain, or entering one that had a higher rate of return. Capital acts a barrier to entry for many informal economy business models and here we see a 'trading-up' phenomenon, whereby small amounts of capital might be leveraged to progress through different types of products moving towards ones where higher mark ups are feasible. For instance if we consider the market for second hand clothes and shoes, or other second hand items like household items or bags, we see that at every stage of the supply chain a small mark up occurs (typically 10-30\%). When we discussed future ambitions for their business with our interviewees those in the second hand markets wished to gain enough working capital to buy a larger bale, bypassing the middlemen and capturing more of the overall value in the retail chain: trading up through value chain capture.

Another form of trading up will be selling a low capital item like vegetables, and then progressing to something that needs more capital investment trading up through business diversification (as demonstrated by interviewees who 'hop-scotching' from one business to the next as their capital grew). So as capital was accumulated an entrepreneur would then diversify into a business such as motorbike taxis, and start employing other informal economy workers or family to run the various new businesses.

Trading up is also facilitated by learning a new skill not shared by others like lawnmower repair or graphic design. If our informal economy entrepreneurs are able to strategically move into a competitive space that is less crowded, for instance through acquiring 'unique' skills or other 
resources, they may then be able to progress from marginality towards a more profitable business model, even if it remains in the informal economy.

There are of course limitations to the research methodology we adopt in this paper. There are thousands of street vendors in Kenya and a different selection of cases may have resulted in different themes emerging. However this work does provide some insights into a much neglected area of enquiry and provide contributions to existing theory that may help shape the direction of future research. We believe that the patterns we have identified and explored are likely to emerge in other similar institutional environments, particularly in other developing countries where the informal economy often still dominates.

\section{References}

Becker, K.F. 2004. The Informal Economy. Department for Infrastructure and Economic Cooperation, SIDA.

Burt, R.L. 1992. Structural Holes. Harvard University Press, Cambridge, MA.

Christensen, L.J., Parsons, H., Fairbourne, J. 2010. Building Entrepreneurship in Subsistence Markets: Microfranchising as an Employment Incubator. Journal of Business Research, 63, 595-60I.

Commission for Africa. 2005. Our Common Interest Report of the Commission for Africa. Available from: <http://www.commissionforafrica.info/wp-content/uploads/2005-report/I I-0305 cr report.pdf> accessed 08.3.13.

Coviello, N.E., Jones, M.V., 2004. Methodological issues in international entrepreneurship research. Journal of Business Venturing 19, 485-508.

Cressy, R.C. 2006. Why do Most Firms Dies Young? Small Business Economics, 26, 103-16.

Daniels, L. 1999. The role of small enterprises in the household and national economy in Kenya: a significant contribution or last resort. World Development, 27, 55-65.

Gartner, W.B., Birley, S., 2002. Introduction to the special issue on qualitative methods in entrepreneurship research. Journal of Business Venturing 17, 387-395.

Gurtoo, A., Williams, C.C. 2009. Entrepreneurship and the informal sector. Entrepreneurship and Innovation, 10, 55-62.

Holt, D., Littlewood, D. and Harrison, R. (2013). The Jua Kali and the Mali-Mali: The Informal/Formal Nexus amongst Kenyan Micro Enterprises. The Trickle Out Africa Project Working Paper Series: 3. January 20I3. ISSN 205 I-6762.

Jagun, A., Heeks, R., Whalley, J. 2008. The impact of mobile phone telephony on developing country micro-enterprise: a Nigerian case study. Information Technologies and International Development, 4, 47-65.

Kapila, S. 2006. Unleashing the entrepreneurial potential of micro and small enterprises in Kenya: some experiences and directions. Paper Prepared for the Commission on Legal Empowerment of the Poor, presented at UNHAITAT, Nairobi, Kenya 26 November

King, K. 1996. Jua Kali Kenya change and development in the informal economy. James Currey Ltd, London.

Kiss, A.N., Wade, M.D., Cavusgil, S.T. 2012. International entrepreneurship research in emerging economies: A critical review and research agenda. Journal of Business Venturing, 27, 266-290.

Kshetri, N. 20I I. Institutional and economic foundation of entrepreneurship in Africa: an overview. Journal of Developmental Entrepreneurship, 16, 9-35.

Leidholm, C. 2002. Small firm dynamics: evidence from Africa and Latin America. Small Business Economics, 18, 225-240. 
London, T., Hart, S.L. 20I0. Next generation business strategies for the base of the pyramid: New approaches for building mutual value. FT Press, London.

Mair, J., Marti, I., 2009. Entrepreneurship in and around institutional voids: a case study from Bangladesh. Journal of Business Venturing 24 (5), 4I9-435.

Mair, J., Marti, J., Ventresca, M.J., 2012. Building Inclusive Markets in Rural Bangladesh: How Intermediaries Work Institutional Voids. Academy of Management Journal 55 (4).

Mulunda, L. 20II. Kenyans pay $25 \%$ more for food. online at

http://kenyauptodate.blogspot.com/201 I/04/kenyans-pay-25-per-cent-more-for-food.html

Mazumdar, D. 1976. The urban informal sector. World Development, 4, 659-679.

Mead, D.M., Leidholm, C. 1998. The dynamics of micro and small enterprise in developing countries, World Development, 26, 6I-74.

Meeks, W.R., Pacheco, D.F., York, J.G. 20I0. The impact of social norms on entrepreneurial action: Evidence from the environmental entrepreneurship context. Journal of Business Venturing, 25,493-509

Neck, H., Brush, C., Allen, E., 2009. The landscape of social entrepreneurship. Business Horizons 52, 13-19.

Nguyen, T.V., Rose, J. 2009. Building trust-Evidence from Vietnamese entrepreneurs. Journal of Business Venturing, 24, 165-182

Nichter, S., Goldmark, L. 2009. Small Firm Growth in Developing Countries. World Development, 37, 1453-1464.

Pisani, M.J., Richardson, C. 2012. Cross-border informal entrepreneurs across the South TexasNorthern Mexico boundary. Entrepreneurship \& Regional Development: An International Journal, 24, 105-121.

Prahalad, C.K. 2004. The Fortune at the Bottom of the Pyramid. Wharton School Publishing.

Román, C., Congregado, E., Millán, J.M. 2012. Start-up incentives: Entrepreneurship policy or active labour market programme? Journal of Business venturing doi:10.1016/j.jbusvent.2012.01.004

Safaricom. 20I I. M-PESA Customer and Agent Numbers. Available from: $<$ http://www.safaricom.co.ke/fileadmin/M-PESA/Documents/statistics/M-PESA Statistics 2.pdf> accessed 08.3.13

Sambu, Z. 20I I. Fuel Prices to Fall Further On Steady Shilling, Says Nyoike. Business Daily, Nairobi, $20 \mathrm{Dec}$.

Schaumburg-Műller, Jeppesen, S., Langevang, T. 2010. Entrepreneurship in Africa report from a workshop 6-8 September. CBDS Working Paper Series, Nr 12/20I0. Centre for Business and Development Studies, Denmark

Simanis, E., Hart, S. 2008. The Base of the Pyramid Protocol: Toward Next Generation BoP Strategy. Cornell University, USA: Center for Sustainable Global Enterprise.

Tan, J., Shao, Y., Tan W.L. 2012. To be different, or to be the same? An exploratory study of isomorphism in the cluster, Journal Business Venturing. doi:10.1016/j.jbusvent.2012.02.003.

Tan, J., Yang, J., Veliyath, R., 2009. Particularistic and system trust among small \& medium enterprises: a comparative study in China's transition economy. Journal of Business Venturing 24, 544-557.

World Bank. 20I I/ Available from: http://www.doingbusiness.org/data/exploreeconomies/kenya/starting-a-business. Accessed 08.3.13. 
Appendix I: Overview of the informal economy interviews

\begin{tabular}{|c|c|c|c|c|c|}
\hline & $\begin{array}{l}\text { Producer or } \\
\text { Manufacturer }\end{array}$ & Supplier & Retailer & $\begin{array}{l}\mathrm{MNC} \\
\text { items }\end{array}$ & $\begin{array}{c}\text { Offers } \\
\text { Services }\end{array}$ \\
\hline sells fruit and clothes & & & $x$ & & \\
\hline Bicycle and Motorbike repair & & & $x$ & $x$ & $x$ \\
\hline Container shop & & $x$ & $x$ & $x$ & \\
\hline Sells meals for market traders & & $\bar{x}$ & & & \\
\hline Sells second hand women's cloth & & & $x$ & $x$ & \\
\hline Hair Salon & & & $x$ & & $\bar{x}$ \\
\hline Tailor & & & & & $x$ \\
\hline Sells Garden plants and trees & $x$ & $x$ & $x$ & & \\
\hline Barber Shop & & & & & $x$ \\
\hline Sells bags and rucksacks & & $x$ & $x$ & $x$ & \\
\hline sells clothes bags & & $x$ & $x$ & $x$ & \\
\hline sells vegetables & $x$ & & $x$ & & \\
\hline bicycle repair & $x$ & $x$ & $x$ & $x$ & $x$ \\
\hline shoe repair & $x$ & $x$ & $x$ & & $x$ \\
\hline sells cooked meals & & $x$ & $x$ & & \\
\hline electronics dealer & & $x$ & $x$ & $x$ & \\
\hline sells women's clothes & & $x$ & $x$ & $x$ & \\
\hline sells ladies bags/boots & & $x$ & $x$ & $x$ & \\
\hline Carpenter & $x$ & & & & $x$ \\
\hline Barber & & & & & $x$ \\
\hline Motorbike taxi & & $x$ & $\bar{x}$ & & $\bar{x}$ \\
\hline Maize Miller & $x$ & & & & \\
\hline Charcoal seller & $x$ & & $x$ & & \\
\hline Tailor & & & & & $x$ \\
\hline Metal sculptures & $x$ & $x$ & $x$ & & \\
\hline Makes beehives & $x$ & $x$ & $x$ & & \\
\hline Natural fibre baskets & $x$ & $x$ & $x$ & & \\
\hline sells hats and jewellery & & $x$ & $x$ & $x$ & \\
\hline water vendor & $x$ & & $x$ & & \\
\hline car wash/ building materials & & $x$ & $x$ & & $x$ \\
\hline sells flowers & & $x$ & $x$ & & \\
\hline chicken business & $x$ & $x$ & $x$ & & \\
\hline sells towels, mats, sheets & & $x$ & $x$ & $x$ & \\
\hline sells potatoes peas and fruit & $x$ & & $x$ & & \\
\hline sells cereal, maize and beans & $x$ & & $x$ & & \\
\hline used clothing and fruit & & $x$ & $x$ & & \\
\hline mali mali (padlocks toys pens) & & $x$ & $x$ & $x$ & \\
\hline Perfume/patterned cloth & & $x$ & $x$ & $x$ & \\
\hline vegetables (traditional/mixed) & $x$ & & $x$ & & \\
\hline taxi driver (car) & & & & & $x$ \\
\hline Children's uniforms and sweater & & $x$ & $x$ & $x$ & \\
\hline Sells plastic shoes & & $x$ & $x$ & $x$ & \\
\hline sells baskets, sheepskins & $x$ & $x$ & $x$ & & \\
\hline sells used women's clothes & & $x$ & $x$ & & \\
\hline sells vegetables & & $x$ & $x$ & & \\
\hline Agro products and animal feed, & $x$ & $x$ & $x$ & $x$ & \\
\hline Car washing and cleaning & & & & & $x$ \\
\hline Furniture producers and sellers & $x$ & $x$ & $x$ & & \\
\hline Welding, metal works, renting & $x$ & $x$ & $x$ & & $x$ \\
\hline Jackets, hats - mostly mens & & $x$ & $x$ & $x$ & \\
\hline
\end{tabular}




\begin{tabular}{|c|c|c|c|c|c|}
\hline Straw Baskets, Jikos & $x$ & $x$ & $x$ & & \\
\hline pots and pans & & $x$ & $x$ & $x$ & \\
\hline Lawnmowers: sale, rent, repair & $x$ & $x$ & $x$ & $\bar{x}$ & $\bar{x}$ \\
\hline Clay pots for gardens & & $x$ & $\mathrm{x}$ & & \\
\hline Garden plants and pots & $x$ & $x$ & $x$ & & \\
\hline Roadside booth & & $x$ & $x$ & $x$ & \\
\hline Hot dog seller & $x$ & $x$ & $x$ & & \\
\hline sells vegetables & $\mathrm{x}$ & $x$ & $x$ & & \\
\hline Charcoal seller & $x$ & $x$ & $x$ & & \\
\hline Curio stands & $x$ & $x$ & $x$ & & \\
\hline
\end{tabular}

i To contextualize these figures the average costs for common items in Kenya Shilling are: Milk 500ml = 30; Sugar 2kg = 190; Bread 400g = I40; Maize Flour 2kg = 93; Rice 2kg = 340; Petrol Liter = II9; Kerosene Liter = 9I; Diesel Liter =III (Mulunda 20I I; Sambu 20II)

ii M-Pesa is the highly successful mobile telephone payment system launched in Kenya by Safaricom, in partnership with Vodafone, on 6th March-2007. By April 20II there were 14,008,319 accounts and 27,988 agent outlets (Safaricom, 20II) 